\title{
Grand Tour: uma contribuição à historia do viajar por prazer e por amor à cultura
}

Valéria Salgueiro

Universidade Federal Fluminense

RESUMO

O trabalho aborda o Grand Tour enquanto fenômeno social, pontuando aspectos técnicos e culturais desses pioneiros fluxos de viagens do século 18 por puro prazer, matrizes dos fluxos de turismo de lazer e cultural do nosso tempo atual. A pesquisa apóia-se nos diários de viagem à Itália de três notáveis grand tourists - o novelista britânico Thobias Smollet, o poeta alemão Johann W. von Goethe e o especialista inglês em antigüidades Richard Payne Knight. Com base em seus relatos, olhamos para as condições de realização do Grand Tour observando rotas e destinos, meios de transporte, guias e acomodações. Entre as questões permeando o universo cultural do grand tourist, destacamos o gosto pela arte e a arquitetura dos antigos, o culto à ruína e a atração de valores estéticos sublimes, em meio às quais podemos distinguir a emergência de uma visualidade dessa experiência de viagem dita "clássica".

Palavras-chave: Grand Tour; antigüidades; ruínas.

\section{ABSTRACT}

This work deals with the Grand Tour as a social phenomenon and points out technical and cultural aspects of these $18^{\text {th }}$ century pioneering travels for pleasure from which derives the leisure and cultural travels of our present time. The research bases upon the writings of three outstanding grand tourists to Italy the British novelist Thobias Smollet, the German poet Johann W. von Goethe and the English expert in antiquities Richard Payne Knight. Based on information provided by their travel accounts, we look at the conditions under which the Grand Tour used to be taken in aspects such as routes and destinations, means of transportation, guides and lodging. The taste for art and architecture of antiques, the cult of ruins and the attraction of sublime aesthetic values are emphasized as those aspects underlying the cultural universe of the grand tourist. The emergence of a visuality derived from the so-called "classic" travel might also be observed.

Keywords: Grand Tour; antiquities; ruins. 
"De certo, estou aprendendo a viajar com essa viagem $(\ldots)^{\prime \prime}$

Viagem à Itália, Johann W. von Goethe

\section{INTRODUÇÃO}

Viagens fazem parte de nosso mundo interligado e complexo, inclusive viagens por puro prazer em que se procura viver algo em tudo diferente da rotina de cada dia - viagens de férias, de descanso, de finais de semana prolongados, em fuga da cidade ou, pelo menos, da cidade onde se vive e trabalha. Viagens de prazer, porém, sem o objetivo de reuniões e contatos profissionais, estão intimamente ligadas justamente a esse mundo ao qual buscam se opor: o mundo do trabalho. De fato, viagens em busca de deleite e emoção, visando ao aprimoramento pessoal e fundadas em categorias de apreciação estética começaram a acontecer em escala crescente exatamente quando o centro irradiador do desenvolvimento capitalista - a Europa - acelerou seu curso de desenvolvimento baseado na indústria e na racionalização do trabalho, ao qual estiveram sempre ligados os conceitos de tempo livre e de ócio, em oposição ao tempo do trabalho.

Este trabalho procura resgatar algumas das principais facetas de um fenômeno social típico da cultura européia do século 18 - o Grand Tour, expressão pela qual vieram a ser denominadas as viagens aristocráticas pelo continente europeu, anteriores à gradativa substituição do tempo orgânico pela regulação do tempo e sua divisão em tempo de trabalho e tempo de lazer no mundo moderno sob o capitalismo. Nele são pontuados aspectos intimamente ligados a esses pioneiros fluxos de viagens por prazer, os quais constituem matrizes remotas dos fluxos de turismo de lazer e cultural do nosso tempo atual.

O texto baseia-se nos diários de viagem à Itália de três notáveis grand tourists do século 18 - o novelista britânico Thobias Smollet ${ }^{1}$, o poeta alemão Johann W. von Goethe ${ }^{2}$ e o especialista inglês em antigüidades e teórico em estética Richard Payne Knight ${ }^{3}$-, todos eles tendo viajado até Roma declaradamente em busca de edificação pessoal e do estudo da cultura dos antigos. Com observação de seus relatos procuramos olhar para as principais motivações das viagens de Grand Tour, destacando aspectos relevantes da nada fácil empreitada de viajar na Europa continental do século 18, quando se tinha de vencer grandes distâncias por áreas acidentadas no lombo de mulas, numa época que ainda desconhecia a navegação marítima a vapor e o trem de ferro. Entre os aspectos abordados no trabalho, destacam-se o gosto pela 
arte e arquitetura dos antigos, o culto à ruína e a valores estéticos sublimes na contemplação da paisagem que acompanhavam o Grand Tour - ou Grand Voyage, ou Grosse Reise -, a partir dos quais podemos distinguir a emergência de uma visualidade dessa experiência de viagem dita "clássica" ${ }^{4}$, distinta daquela engendrada pelo olhar romântico do século 19 e da que vem se configurando pelo olhar contemporâneo, cheio de tecnologias.

\section{O GRAND TOURIST}

Um novo tipo de viajante surge no século 18 em conexão com as transformações econômicas e culturais na Europa do Iluminismo e da Revolução Industrial. Trata-se aqui não do viajante de expedições de guerras e conquistas, não do missionário ou do peregrino, e nem do estudioso ou cientista natural, ou do diplomata em missão oficial, mas sim do grand tourist, conforme era chamado o viajante amante da cultura dos antigos e de seus monumentos, com um gosto exacerbado por ruínas que beirava a obsessão e uma inclinação inusitada para contemplar paisagens com seu olhar armado no enquadramento de amplas vistas panorâmicas, compostas segundo um idioma permeado por valores estéticos sublimes. Um viajante dispondo acima de tudo de recursos e tempo nas primeiras viagens registradas pela historiografia da prática social de viajar por puro prazer e por amor à cultura.

A viagem por prazer, não como um ato isolado por um ou outro viajante mais excêntrico e curioso, mas sim como um fenômeno social, configurando fluxos com origens e, sobretudo, destinos específicos, na verdade começou a assumir seus contornos já ao final do século 17, tornando-se mais e mais freqüente, porém, após o Tratado de Paz de Utrecht, em 1715. Tanto quanto é possível traçar, por muitos séculos lugares na Europa vinham atraindo viajantes, mas foi no século 18 que um tour continental veio de fato tornar-se parte essencial da educação de todo inglês de posse, e isso prosseguiu por todo o século, sendo interrompido apenas durante a Guerra dos Sete Anos (17561763), finda a qual os Grand Tours foram retomados em escala ainda maior.

Viagens sempre atraem mais viagens e a ampla convicção de que um grande número de pessoas estava viajando contribuía para ampliar a percepção da importância social do Grand Tour ${ }^{6}$, despertando o interesse de novos turistas. Conforme observou Adam Smith, o costume tornava-se cada vez mais freqüente entre as famílias ricas, que mandavam seus filhos viajar para países estrangeiros ainda jovens, para aprender uma ou duas línguas, edificar-se e distrair-se ${ }^{7}$. Ao final do século 17, o turismo era essencialmente praticado por filhos da aristocracia e da chamada gentry (pequena nobreza). Mas, aos poucos, essa clientela foi se ampliando, de modo que, ao final do século 
18, o Grand Tour estava já firmemente estabelecido para os filhos da classe média urbana melhor situada, formada por burgueses prósperos e emergentes do setor de serviços que a indústria indiretamente engendrava ${ }^{8}$.

Nomes importantes realizaram um Grand Tour como, por exemplo, Joseph Addison, Joachin Winckelmann, Johann W. Goethe, Horace Walpole e Thomas Gray, dentre tantos outros intelectuais, filósofos, artistas, viajantes cuja proveniência era primordialmente a Inglaterra, a França e a Alemanha, seguidas por outras nacionalidades, em menor escala. O fenômeno do Grand Tour foi, contudo, acima de tudo inglês, e isto se explica pelas circunstâncias vividas por aquela nação à época: a Inglaterra havia triunfado na Índia e na América do Norte, e era a nação que estava liderando o mundo no comércio e nos métodos industriais e agrícolas de produção. Grupos nacionais, direta ou indiretamente se beneficiavam da geração de riqueza no próprio país e por todo o mundo sob seu controle, o que fazia aumentar, mais do que em qualquer momento anterior, o dinheiro para gastar com o prazer.

\section{Rotas e DESTINOS}

A idéia de prazer no período que observamos envolvia ganhar novos horizontes físicos e culturais, ao menos entre os mais afortunados. À medida que findava o século 18 , porém, o turismo ia se tornando cada vez menos uma prática exclusiva dos ricos, crescendo gradativamente o número de turistas menos afluentes viajando pelo Continente. Alguns faziam uma viagem mais curta e menos custosa, e nem todos iam até a Itália, optando por viajar até Paris e os Países Baixos, por exemplo. O verdadeiro Grand Tour, porém, envolvia essencialmente, além de uma viagem a Paris, um circuito pelas principais cidades italianas - Roma, Veneza, Florença e Nápoles, nessa ordem de importância.

Se considerarmos as dificuldades envolvidas na viagem devido às precárias condições de superação da distância entre os lugares, chegar até Roma no século 18 era uma façanha absolutamente corajosa. Para os que partiam da Inglaterra, o cruzamento do Canal da Mancha constituía parte realmente crítica da viagem. Ventos, ondas altas e cais precários tornavam o embarque e o desembarque uma aventura aterrorizante, acompanhada por náuseas, vômitos, sustos e até ferimentos na troca de embarcações maiores por barcos menores, necessários em vista de ancoradouros inadequados para as embarcações de maior porte. Não havia ainda o navio a vapor no século 18 , sendo a travessia do Canal da Mancha feita ainda por embarcações à vela — uma aventura verdadeiramente apavorante para muitos que pela primeira vez em suas vidas estavam vendo o mar e, simultaneamente, tendo de enfrentá-lo. 
Uma vez atingido o continente europeu, diversas rotas poderiam ser tomadas pelo grand tourist cuja meta eram lugares como Hannover, Dresden ou Viena. A mais procurada, contudo, era a que ligava o porto de Calais a $\mathrm{Pa}$ ris. Na verdade, chegar até Paris constituía boa parte das expectativas do viajante cujo sonho não era a França provincial, com suas horríveis estradas e formas modestas de vida, mas sim a grande metrópole parisiense, que podia oferecer todas as aventuras e atividades da vida social e todas as facilidades de conforto, sendo ao mesmo tempo diferente, excitante e cheia de novidades.

Após permanecer por algum tempo em Paris, tempo esse que poderia variar bastante em função das posses do viajante, o destino era então a Itália. O mais comum era tomar a direção de Lion, onde o problema da travessia dos Alpes teria de ser encarado. Na verdade, uma vez em Lion os turistas tinham duas alternativas para seguir em frente rumo ao sul: ou atravessar os Alpes até Turin, ou enfrentar o Mar Mediterrâneo. E nenhuma das duas alternativas era muito animadora. Por mar, havia o risco de tempestades, piratas e o inconveniente de ventos contrários que implicavam atrasos na partida de até mais de um dia. Somavam-se a tudo isso as más acomodações disponíveis nas embarcações, desestimulando a viagem marítima de tal modo que a maioria dos viajantes acabava preferindo viajar por terra, cruzando os Alpes $^{9}$. A rota mais comum de Lion para Turin era passando pelo Monte Cenis, uma passagem totalmente inviável para o tráfego de veículos de roda, sendo por isso necessário desmontar a carruagem e transportar toda a tralha, inclusive a bagagem, no lombo de mulas, enquanto o viajante era mais provável de ser carregado por robustos carregadores montanheses em cadeiras de viagem do tipo de liteiras. Nesse caso, com um carregador na frente e outro atrás, $o$ grand tourist viajava sentado, ... "contemplando" a sublime paisagem alpina.

A partir de Turin os viajantes seguiam para as cidades mais procuradas - Veneza, Florença, Roma - por diversas rotas, dependendo dos planos pessoais da viagem, da estação do ano, dos recursos financeiros, do desejo de encontrar amigos e conhecidos, dos interesses e curiosidades pessoais por monumentos, enfim, de uma série de fatores. Os que seguiam para o sul em direção a Roma e Nápoles, e mais para o sul ainda, em direção à Sicília, invariavelmente possuíam um interesse maior por arte, arquitetura e antigüidades. Nem todos chegavam até esse extremo, porém, como o fizeram Goethe e Knight. Mas é importante reter que Roma era o ponto alto, o apogeu do Grand Tour, com o qual o viajante podia dar-se por realizado. Quando acontecia de não ser atingida a meta de chegar até esta cidade, o viajante podia sentir-se inferior diante de outros que o tinham conseguido. Isto era evitado com todo tipo de sacrifício para que o tour não deixasse em hipótese alguma de incluir a capital do antigo Império, sendo tolerados muitos desconfortos e perigos, contidas as despesas e redobrada a paciência com os hábitos locais, tão irri- 
tantes para a sensibilidade e exigências de nobres britânicos. O lugar destacado de Roma no tour do viajante clássico do século 18 pode ser sintetizado nas palavras de Goethe, que apesar de lamentar a destruição implacável do tempo e da ação humana sobre suas relíquias, maravilha-se totalmente quando chega à cidade:

(...) Noutras partes, tem-se de procurar o que é significativo; aqui, ele se impõe sobremaneira, inundando-nos. Caminhando-se, parando aqui e ali, por toda parte descortinam-se à nossa frente paisagens de todos os tipos, palácios e ruínas, jardins e matas, amplidão e exigüidade, casinhas, estábulos, arcos do triunfo, colunas, e, com freqüência, tudo junto e tão próximo que se poderia desenhar o conjunto numa única folha de papel. Mil lápis seriam necessários para registrá-lo, de nada nos vale uma única pena! E, quando a noite chega, está-se exausto de tanto contemplar e admirar ${ }^{10}$.

\section{Meios DE TRANSPORTE}

Vencer longos e acidentados percursos integra um elenco de muitas dificuldades em viajar numa época de ainda bem pouca tecnologia nas comunicações. O grand tourist não viajava de trem e nem em embarcações a vapor, conforme já o fazia o viajante do século 19 , mas sim a pé ou chacoalhando em estradas ruins, sendo conduzido no lombo de animais de carga ou em carroças desengonçadas e carruagens duras. Cavalos eram muito usados e essa forma de viajar envolvia rituais que hoje desconhecemos inteiramente. Os animais tinham de ser trocados entre estações, por exemplo, para seu descanso e alimentação, e por isso as hospedarias onde os viajantes pernoitavam ou permaneciam nos intervalos de cada trecho eram também estábulos para a troca de animais no reabastecimento das carruagens que tinham de seguir viagem. Sendo em geral mais resistentes do que cavalos, mulas eram muito usadas nas subidas, transportando bagagem e pessoas. Esta dura função podia às vezes ser desempenhada por humanos, mesmo, que carregavam outros humanos em pares, sustentando cadeiras de viagem, um tipo de liteira em que o viajante, confiando nos que o transportavam nesse meio hoje tão curioso para nós, aproveitava a oportunidade para apreciar as belezas cênicas da paisagem alpina ${ }^{11}$.

Muitas vezes guias eram contratados para dar explicações e mostrar pontos de interesse durante paradas para o descanso dos carregadores e dos animais. No percurso de Nice para a Itália, se o viajante optava pela cadeira, cerca de seis a oito carregadores eram empregados, revezando-se ao longo do 
percurso no sustento da carga da própria cadeira e mais a do "passageiro", o qual poderia pagar um preço extra pelo serviço quando acontecia de estar muito além dos limites de peso tolerados pelos carregadores.

Nos caminhos estreitos, cortados junto a montanhas íngremes, longas filas de mulas carregadas se formavam em passagens cuja largura às vezes não excedia um pé e meio (pouco mais do que 50 centímetros). Sendo impossível duas mulas se cruzarem em um caminho assim tão estreito, os tropeiros faziam uso de certos trechos mais largos de quando em quando, criados justamente para resolver o difícil problema do encontro de tropas. Tratava-se de uma espécie de cotovelo em diferentes partes do caminho, de tal modo que, quando duas tropas de mulas se encontravam, a menos numerosa ocupava esse trecho mais largo, enquanto a outra passava por fora ${ }^{12}$. Tudo isso acontecia em meio à freqüente ameaça de avalanches, quedas monumentais de neve acumulada nas montanhas altas que desciam de uma só vez, decepando árvores e arrastando tudo que estivesse na frente. Em momentos assim, as forças avassaladoras da natureza convertiam a experiência estética do êxtase diante da paisagem grandiosa pelo viajante em tragédia de fato.

Algumas rotas na França permitiam alternativas na forma de viajar. De Paris para Lion, por exemplo, podia-se ir por "diligência”. Nesta, a pessoa viajava espremida em um dos oito assentos de uma carruagem, numa viagem que durava algo em torno de cinco dias. Isso, evidentemente, exigia que o grupo de passageiros transportados fizesse pernoites ao longo do trajeto, o que não era exatamente algo sempre agradável. Além dos corriqueiros desentendimentos, as pessoas poderiam, por exemplo, ser retiradas da cama para prosseguir viagem às quatro, às três, ou até às duas horas da manhã, pois não se tinham ainda os previsíveis horários programados de hoje. Uma outra forma de vencer este percurso entre Paris e Lion era alugando uma carruagem e quatro cavalos, o que além de mais caro poderia ser muito demorado. Havia ainda uma outra alternativa que era uma post-chaise, uma espécie de carro fechado e com quatro rodas, usado para transportar pessoas, encomendas e correspondência, puxado por dois cavalos rápidos, trocados a cada posto de correios do percurso ${ }^{13}$.

$\mathrm{Na}$ Itália era também comum o grand tourist viajar utilizando um meio de transporte chamado por sediola. Tratava-se, na verdade, de uma caleche de quatro rodas e dois assentos, puxada por uma parelha de cavalos, conduzida por alguém contratado para isso - o vetturino - nome pelo qual era chamado o homem que conduzia e levava a bagagem numa carruagem, também chamada por sedia ${ }^{14}$.

Em Veneza, o transporte era feito por gôndolas. Já de Veneza para Ferrara, se utilizava barco postal para a travessia de lagos. A viagem por mar era muitas vezes a forma adotada para superar acidentes físicos e distâncias em 
percursos nos quais não havia o que ver de muito interesse. Viagens para distâncias maiores, como de Nápoles para a Sicília, por exemplo, eram feitas por paquete, embarcação que andava conforme o vento. O paquete que Goethe utilizou neste trajeto foi construído na América e possuía, conforme seu relato, "camarotes confortáveis e leitos individuais" 15 , embora nem por isso aliviasse suas freqüentes náuseas e ânsias de vômito. Também nesta parte da Itália a viagem por mar podia aprontar muitas surpresas desagradáveis ao grand tourist, e até tragédias. A força do vapor aplicada aos meios de transporte iniciou-se apenas em torno de 1780, com a construção dos primeiros barcos experimentais na França, nos Estados Unidos e na Escócia, sendo que até o advento desse tipo de força motriz e emprego do ferro no casco, as embarcações eram em madeira, sendo o choque contra rochedos fatal para sua integrida$\mathrm{de}^{16}$. Barcos podiam perder o rumo e trazer grandes sobressaltos para uma viagem, conforme relato de Goethe na volta da Sicília para Nápoles, numa sublime narrativa do episódio:

(...) contemplávamos agora com pavor o nosso destino. Embora a noite não nos permitisse distinguir o perigo crescente, notávamos que o navio, a balançar-se e a inclinar-se, aproximava-se dos rochedos cada vez mais negros à nossa frente, enquanto uma tênue luz crepuscular esparramava-se ainda sobre o mar $^{17}$.

\section{CAMINHOS E ESTRADAS}

A extensão dos percursos das jornadas de viagem nas condições das estradas e dos transportes da época variava de quatro a vinte milhas por dia (entre seis e trinta quilômetros, aproximadamente), exigindo dar partida antes do dia clarear para bom rendimento da viagem. ${ }^{18}$

Trajetos entre os locais visitados podiam ser percorridos a pé do ponto de hospedagem ou parada até o lugar de interesse da visita, em função da precariedade do trajeto e do grau de aclividade apresentado. Goethe relata um recurso curioso para imprimir maior eficiência a um percurso feito por ele e pelo artista alemão Johann H. W. Tischbein nas redondezas de Nápoles, em que os guias por eles contratados subiam a montanha com um bastão na mão para dar o impulso necessário à subida, e um cinto de couro atado à cintura ao qual os dois viajantes alemães se agarravam para serem "arrastados" pelos guias caminho acima, facilitando-lhe assim o esforço da subida ${ }^{19}$.

As estradas eram de terra ou de pedra, muitas vezes não mais do que apenas caminhos lamacentos, ainda não trilhados, em direção às montanhas. Ocorria que, em alguns pontos elevados do trajeto, tornava-se necessário fa- 
zer o percurso montado numa mula, dispensando a carruagem, e isso era bem cansativo. A viagem tornava-se difícil também na travessia de cursos de rios, especialmente quando chovia e o leito se elevava. Nem sempre havia pontes, sendo então necessário atravessar rios a pé ou por meio de embarcações frágeis e precárias. Caminhos mais difíceis, que só podiam ser percorridos a pé ou a cavalo, dependiam sempre da existência de uma hospedaria no curso para ter onde alimentar os animais.

Conforme Smollet, as estradas, além de precárias, eram infestadas de ladrões e contrabandistas. Mas, segundo o autor, o lugar dos chantagistas era, sobretudo, Roma, onde havia inclusive muitos charlatões ingleses sempre prontos a iludir viajantes entusiasmados com a venda de coisas sem valor, como obras de pintura de artistas célebres - falsificadas! Os ingleses, que eram sabidamente os mais ricos viajantes, eram igualmente os mais atraídos para negócios falsos. Em parte isso ocorria também por suas ambições de se tornarem connoisseurs em tudo o que julgavam importante — pintura, música, estatuária e arquitetura — tão logo pisassem o solo italiano. Carregadores desonestos, por sua vez, "sumiam" com malas e a bagagem do viajante. Conforme Goethe, a habitação que ele ocupava com o artista alemão Tischbein na cidade de Nápoles nunca ficava totalmente só, de modo que sempre permanecia alguém de plantão em casa quando um deles saía para ver antigüidades, fazer visitas aos locais, etc. Além de todos esses problemas, havia freqüentes riscos à segurança do viajante: segundo Goethe, assassinatos eram corriqueiros, e, não raro, pessoas eram mortas a facadas ${ }^{20}$, o que indica o grau de motivação de que mesmo assim se imbuía o grand tourist para enfrentar as inevitáveis adversidades.

\section{GUIAS}

Relatos de viagem e coleções de vistas de lugares constituíam as formas usuais de guias impressos para o Grand Tour, e era com essas formas embrionárias de guias que o viajante se munia para se informar e aproveitar o máximo da viagem. Em meados do século 18 existiam já diversos guias impressos tendo como preocupação orientar o viajante na visita a locais célebres e antigüidades de Roma. Algumas leituras constituíam parte da preparação para a viagem, entre as quais tratados e obras célebres de autores antigos e renascentistas influentes nas artes e na arquitetura. Goethe, por exemplo, leu o arquiteto italiano Andrea Palladio (1508 - 1580), célebre por sua interpretação de valores clássicos da arquitetura antiga à época do Renascimento. O poeta alemão também levou consigo para a Itália o conhecido guia à época de D. J. J. Volkmann, Historisch-kritische Nachrichten von Italien (1778), buscando fa- 
miliarizar-se ao máximo com a arquitetura e os monumentos romanos já vistos e descritos por viajantes anteriores. A famosíssima História da arte na Antigüidade (1764), de Joachin Winckelmann, ainda hoje básica para qualquer historiador de arte, foi muito lida por viajantes em Roma, tendo se tornado à época um verdadeiro must para os que buscavam nos antigos uma veneração quase religiosa. Dentre os guias mais celebrados, figurava também a conhecida coleção de vistas da cidade de Roma por Giovanni Battista Piranesi - a Vedute di Roma -, tão difundida até hoje e muito apreciada.

Além das leituras, uma rede de conhecimentos, apoiada em comerciantes, banqueiros, diplomatas, artistas e estudiosos, facilitava a viagem do grand tourist. Através dessas redes estruturadas em posições e relações pessoais, e acionadas através de cartas de apresentação, cartas de recomendação, salvoscondutos e bilhetes de amigos e conhecidos, facilidades eram conseguidas como reservas em hospedarias, além de contatos com tipos locais, para servirem como guias, ou com connoisseurs, para que estes abrissem suas coleções particulares de antigüidades à inspeção do viajante. É oportuno lembrar que museus públicos, franqueados à visitação, são um fenômeno do século $19 \mathrm{e}$ produto de uma visão de educação pública que não havia ainda no período que observamos.

Pessoas amigas e já familiarizadas com os lugares poderiam ser excelentes guias para seus compatriotas recém-chegados. O pintor Tischbein, por exemplo, tornou-se um guia exemplar, conforme palavras de seu amigo Goethe, tal qual "um guia inglês..." ${ }^{21}$, uma expressão que bem evidencia o imaginário alemão dos ingleses, aos quais era atribuída uma superioridade em questões de viagem. Moradores locais podiam também assumir a função de guias, carregando consigo pertences do viajante e objetos necessários a uma visita mais distante, como alimentos, água e pastas de artistas, como o fez Kniep, artista paisagista que acompanhou Goethe de Nápoles à Sicília. Em cada lugar que visitava, aliás, Goethe contratava um guia para levá-lo a pontos especiais de contemplação das paisagens, cada uma "constituindo o cenário ideal para uma cena idílica" 22 que, na certa, servir-lhe-iam como inspiração para seus escritos quando de volta. Em várias passagens de seu diário Goethe observa sobre essa condição de guia por parte de moradores locais. A orientação sobre o que ver e visitar, e a informação sobre a história do lugar e das edificações, além de fatos notáveis ligados a pontos de interesse eram, com freqüência, contratadas no ato, entre pessoas da população que se apresentavam para o ofício, numa época em que a profissionalização do guia era algo ainda totalmente impensável e sem qualquer treinamento.

Em Roma, para evitar falsificações e prejuízos na aquisição de peças por colecionadores estrangeiros, estes eram aconselhados a contratar um "especialista" em antigüidades para instruí-los sobre todas as curiosidades da cida- 
de, o que se tornava absolutamente necessário quando alguém queria tornarse um connoisseur em matéria de pintura, escultura e arquitetura ${ }^{23}$.

\section{ACOMODAÇÕES}

Segundo o editor do diário de viagem de Thobias Smollet, Frank Felsenstein, viajar no século 18 envolvia inevitavelmente brigas contínuas com donos de hospedaria e tropeiros, e contratempos de todo tipo. E, "enquanto para a maioria dos viajantes isso não era relatado, Smollet era um observador honesto e que realmente registrava o que via". ${ }^{24}$ Conforme Felsenstein, seus relatos detalhados trazem a essência do que era viajar pela Europa continental antes do advento do trem.

Com freqüência Goethe lastima-se "das mais desconfortáveis acomodações... e de ter que preparar a própria comida”" ${ }^{25}$, relatando sobre hospedarias "sem elegância", com seus serviços de hospedagem ainda não organizados para atender aos diferentes níveis sociais com que o grand tourist tinha de conviver. Não atendido com acomodações a seu gosto, não restava alternativa ao viajante mais rico do que "misturar-se" com outros, observa Smollet, uma prática impensável para os padrões atuais de viagem em pacotes fechados no ato da compra, que evitam "surpresas". Às vezes faltavam hospedarias, restando a alternativa da hospedagem familiar. Nessas circunstâncias, contatos com pessoas do lugar tornavam-se parte da viagem, com acertos e negociações tendo de ser feitos a todo momento para atender às necessidades mais básicas do turista.

Em Roma os ingleses apreciavam ficar hospedados na Praça d'Espanha, onde havia albergues públicos e razoáveis hospedarias particulares, mas Goethe reclama da falta de hospedarias na Sicília para o forasteiro, que tinha de sair em busca de uma acomodação "sempre incerta". Conforme o escritor alemão, o viajante “(...) se encontra um quarto, este tem de passar por uma limpeza. Cadeiras e bancos inexistem, apenas banquinhos baixos, feitos de madeira dura; mesas também não há" ${ }^{26}$. Faltava também um local para comer e para cozinhar, de modo que a comida tinha que ser feita na casa de um morador local, em troca de algum pagamento.

Em Nápoles locais de hospedagem poderiam ser "albergues", os quais eram considerados por Goethe como "muito ruins”. Este autor, aliás, fala com freqüência de pousadas ruins, que tornavam a viagem, para quem a fazia só e pela primeira vez, em algo terrível. Mas o próprio poeta se consolava, esforçando-se por tudo superar para bem de melhor atingir sua verdadeira meta. Como dizia, “... eu nada mais queria do que ver este país, qualquer que fosse 
o custo; e ainda que me arrastem até Roma preso à roda de Ixion, não desejo me queixar" 27 .

\section{NO RASTRO DE ANTIGÜIDADES}

A recompensa a tantos sacrifícios na viagem era a possibilidade de poder verificar in loco os monumentos que se conhecia até então apenas de ouvir falar, de ler nos diários de viagem dos outros, ou de ver em livros de estampas que iam surgindo nos principais pólos culturais europeus. Era tal o interesse do grand tourist por antigüidades que as dificuldades não chegavam a propriamente detê-lo em sua avidez por monumentos do passado.

No culto ao antigo característico do século 18 a viagem desempenhou um papel muito importante no reconhecimento, assim como na descrição e representação visual de monumentos. Pode-se dizer que foi com os Grand Tours que se iniciaram os estudos sistemáticos da ainda embrionária ciência da arqueologia e as primeiras teorizações modernas sobre conservação/preservação de monumentos históricos, questão que tem atraído tantos debates desde Ruskin e Violet-le-Duc. Sob o olhar de viajantes que viam no estudo dos antigos o sentido maior de sua viagem, monumentos puderam ser localizados, identificados e estudados, para serem por fim tornados conhecidos do público em obras ilustradas e pioneiras de arqueologia e de história da arte e da arquitetura.

O culto ao antigo do século 18 foi em boa parte alimentado com escavações e descobertas, sobretudo na Itália, com suas ruínas e suas cidades de Herculano e Pompéia, soterradas por tantos séculos pela erupção do vulcão Vesúvio de 79 d.C.. Em torno de 1740, pouco depois de iniciadas as escavações de Herculano, estátuas de bronze, bustos de mármore e colunas não paravam de ser descobertos. Poucos anos depois começaram as escavações de Pompéia, e vieram novas descobertas. Esses fatos eram todos muito excitantes para o crescente interesse pela história da época, e nenhum Grand Tour era considerado completo sem uma visita a esses dois locais e às várias coleções reunidas em Nápoles, onde objetos escavados podiam ser inspecionados pelo estudioso diletante. Foi tanta a influência que essas escavações e suas descobertas exerceram sobre a mentalidade européia à época que se acreditava que tudo isso representava uma segunda fase do Renascimento ${ }^{28}$.

A influência das escavações de Pompéia e Herculano teve também muitos impactos no gosto e nos valores estéticos do europeu ao final do século 18, como, por exemplo, a apreciação de mobília e louça de decoração, inspiradas no mobiliário antigo. A louça "etrusca" tornou-se famosa, assim como 
modelos de cadeira que reproduziam vários motivos clássicos recuperados das escavações, chamados Herculanium.

O culto ao antigo que acompanhou o Grand Tour à Itália também não se esgotava na viagem, tendo desdobramentos posteriores à chegada dos viajantes a seus países, especialmente na Inglaterra, onde eles eram em maior número e mais ativos. Um desses desdobramentos foi a fundação de sociedades reunindo pessoas com interesse em antigüidades. A Society of Dilettanti, fundada em 1734 por um grupo de gentlemen que havia viajado em um tour à Itália, tinha como preocupação central promover a investigação e a publicação dos resquícios das grandes civilizações do passado. Além de conceder bolsas para viagem de estudos e pesquisas sobre antigüidades na Itália, a Society of Dilettanti publicava obras sobre o assunto como, por exemplo, a Antiquities of Athens (1762), de James Stuart e Nicholas Revett ${ }^{29}$.

O objetivo do Grand Tour de ampliar o conhecimento sobre a história e a arte dos antigos, um hábito aristocrático e altamente em moda, pressupunha a elaboração de um diário de viagem, e, se possível, a ilustração dos monumentos observados. A escrita do diário e a ilustração faziam parte de um ritual metodológico que ia se impondo, cujo ponto alto era a sua publicação, ao retorno do viajante, o que ampliava o conhecimento e despertava o interesse dos leitores para novos projetos de viagem e novos conhecimentos. A publicação conferia também bastante prestígio ao autor, que procurava referir-se a passagens históricas e a textos da literatura clássica para estabelecer relações com o que era visto no ato da viagem, pois isso denotava um saber em moda e compartilhado com o público leitor. Um dos primeiros ingleses notáveis a fazer o Grand Tour, Joseph Addison, procurou observar a Itália através dos olhos dos antigos poetas latinos, como Horácio, conforme ele mesmo afirma em seu livro de viagem Remarks on the Several Parts of Italy $(1705)^{30}$. Exibir conhecimento e familiaridade com a arte, a arquitetura e a literatura clássicas concedia tal prestígio intelectual ao viajante que Richard Payne Knight, no diário de sua viagem à Sicília, utilizou-se de expressões em latim e de textos de Homero e Virgílio em suas observações e descrições de templos, da paisagem e de portos por ele visitados. Quando em Selinus, local fundado por colonizadores gregos em torno de 650 a.C., Knight observa sobre a vegetação "seca e infecunda", a qual "Virgílio [em sua obra Eneida] chamou por Palmosa Selinus". ${ }^{31}$ Segundo a editora de seu diário só recentemente publicado (1986), as referências de Knight a detalhes históricos e a textos clássicos teriam sido acrescentadas depois de elaborado o diário, após o retorno de sua expedição, uma vez que Knight não possuía uma cultura humanista suficientemente ampla para estabelecer relações de modo automático, no ato da viagem, conforme seus escritos à primeira vista podem sugerir ${ }^{32}$. Admitida esta hipótese, isso só viria confirmar quanto a familiaridade com o antigo deno- 
tava status intelectual e convinha ao gosto da época, podendo mesmo ser "aplicada" ao relato de uma viagem para imprimir-lhe atualidade e potenciar sua recepção pública.

Viagens como a de Knight, dentro do mais profundo espírito do Grand Tour, não se destinavam, portanto, à aventura simplesmente, mas se justificavam pela ampliação dos horizontes culturais do viajante culto e interessado, e buscavam recapturar o espírito dos antigos. Grand tourists imbuídos desse espírito não contemplavam mármores por prazer, simplesmente, mas para verificar seu valor como "fragmentos" da história ou visando à educação de estudiosos e artistas. Não apenas para "ver", mas sobretudo para "conhecer", a viagem dentro do espírito do Grand Tour cumpria assim objetivos estabelecidos, num um programa de cuja elaboração participavam sociedades como a Society of Dilettanti que imprimiam legitimidade tanto aos estudos sob sua chancela quanto aos saques ingleses de remanescentes antigos, como os famosos “mármores de Elgin” do Museu Britânico.

Os periódicos na Inglaterra anunciavam seguidamente em suas listas de novas publicações um número de títulos sobre antigüidades, história e topografia, assim como publicavam resenhas de trabalhos sobre o assunto, o que revela a popularidade que haviam atingido obras girando em torno do tema antigüidades. Muito desse conhecimento provinha de descrições e estudos de monumentos visitados por grand tourists. Alguns títulos novos divulgados no periódico londrino Gentleman's Magazine, por exemplo, ilustram essa contribuição das viagens à Itália e seus relatos, como a obra $A$ Visit to Milan, Florence, and Rome, the subterraneous Cities of Herculaneum and Pompeii, and the Character of Vesuvius, in 1821, por W. T. P. Shortt ${ }^{33}$, como também a Archeologia; or Miscellaneous Tracts relating to Antiquity, publicado pela Society of Antiquaries, de Londres ${ }^{34}$, fundada em $1717 .{ }^{35}$ Além de resenhar obras sobre antigüidades da Inglaterra, da Europa e até de outros continentes, como a Ásia, e de publicar relatos de viagem seriadamente, este último periódico possuía também uma seção chamada "Antiquarian and Philosophical Research", dedicada à divulgação do conhecimento. Essa seção anunciava importantes descobertas de arqueologia e antigüidades em geral, resultados de expedições a locais habitados por povos antigos, debates girando em torno de hipóteses sobre o significado de monumentos do passado e suas características (época, origem, uso), escavações, e tudo o mais que pudesse estar ocorrendo nesse campo.

\section{O GOSTO POR RUÍNAS}

Ruínas são sinais visíveis do passado, de um tempo que se foi, deixando lições para o presente e o futuro. Para o grand tourist, a Itália era, nesse sentido, 
extremamente estimulante: as ruínas de seus monumentos antigos instruíam e ao mesmo tempo alimentavam a imaginação do viajante, fornecendo-lhe "matéria" para a descrição e o estudo, bem como para alimentar a fantasia.

Quando se iniciaram as escavações das cidades de Pompéia e Herculano, o interesse pelo passado por parte de artistas, escritores, interessados em história e colecionadores, atingiu níveis realmente inéditos, e o prazer por ruínas romanas cresceu para o ponto de "embriaguez", segundo Maculay ${ }^{36}$. As escavações alimentavam esse prazer estético, e o gosto por ruínas, por sua vez, cultivado na arte e na literatura, incentivava o interesse em conhecer os monumentos remanescentes da cultura dos antigos que iam sendo descobertos e estudados. Lares alemães passaram a ter penduradas em suas paredes, como decoração, imagens gravadas de ruínas por artistas italianos dessa especialidade, como Piranesi, Pannini e Salvator Rosa, ou italianizados, como Poussin e Claude Lorrain. E Goethe, em Roma, fez-se retratar por Tischbein de modo emblemático: recostado a ruínas na região da Campanha romana, rodeado por remanescentes de colunas, frisos e volutas jônicas espalhadas pelo terreno, ele traja uma túnica clara e emite um olhar enigmático, dirigido ao horizonte distante.

A grande quantidade de ruínas dos tempos áureos do Império Romano satisfazia diferentes demandas de gosto dos viajantes influenciados pela renovada percepção da história como um processo de evolução lógica, e não meramente como uma simples sucessão cronológica de acontecimentos, acarretando essa postura profundas mudanças de atitude e de compreensão humana diante da vida. Uma epidemia de historiadores tomou conta da Europa com o passar do século 18, movidos pela proposta de interpretar seu mundo escrevendo relatos em muitos volumes a respeito do passado dos vários lugares.

$\mathrm{Na}$ arte, a ruína tornou-se uma febre atingindo artistas que nela encontravam um desafio especial para desenvolver soluções técnicas e artísticas na representação de texturas de superfícies desgastadas pelo tempo, da cor dos objetos alterada pela idade, da erva brotando das paredes, entre outros. O entusiasmo estético por ruínas da segunda metade do século 18 chegou, porém, a níveis de uma paixão que extrapolou o âmbito da literatura e da pintura: ruínas chegavam a ser intencionalmente "manufaturadas" em fachadas de prédios, enquanto monumentos famosos eram propositalmente "arruinados", e jardins tornavam-se particularmente apreciados quando o paisagista providenciava em sua composição um arranjo de pedras ... como uma ruína. Não é difícil avaliar, nessas circunstâncias, os papéis que a observação, a contemplação e a representação de ruínas tiveram nas viagens turísticas pelo continente europeu no século 18, destacadamente na Itália, onde havia ruínas em profusão. 


\section{GRAND TOURS E A ARTE}

A arte era parte essencial da viagem aristocrática, que o viajante cultivava tanto contemplando quanto produzindo. Muitos dos viajantes em Grand Tour eram também artistas amadores, sendo essa a única forma de se possuir registros visuais numa época ainda tão distante da prática câmera fotográfica portátil que temos hoje. Observações documentadas visualmente tornavamse mais e mais valorizadas na emergente cultura do Iluminismo, para a qual a verificação empírica e seu registro eram pressupostos de validade e confiabilidade do saber. Desse modo, fazer desenhos, ou levar um artista para essa tarefa, foi se tornando essencial e bastante freqüente. Buscar algum treinamento artístico para permitir ao menos alguns esboços rápidos também ocorria com freqüência. Os que possuíam recursos, levavam consigo um artista ou contratavam um no decurso da viagem. Goethe, por exemplo, reuniu-se ao artista Tischbein, em Roma, que o acompanhou até Nápoles. Já de Nápoles até a Sicília, o escritor alemão fez-se acompanhar pelo artista paisagista Kniep, contratado especificamente nessa etapa de sua viagem para fazer registros de paisagens, detalhes de arquitetura e monumentos. Porém, como nem todos os viajantes à Itália podiam contratar artistas ou adquirir obras como, por exemplo, do alemão Philip Hackert, que atuava naquele país, ou de celebridades, como o veneziano Canaletto e o romano Piranesi, ampliou-se bastante o hábito de esboçar e pintar pelo próprio viajante, já que essa era a única forma de levar para casa retratos dos lugares visitados.

O temário dessa produção artística relacionada ao Grand Tour era formado predominantemente por paisagens panorâmicas ou fragmentos (recortes) de paisagens com algum acidente físico de especial interesse (vulcão, baía, lago, vale, litoral, etc.), vistas de cidades (vedute) de apelo histórico, monumentos arquitetônicos antigos, além de detalhes de ornamentação e de elementos arquitetônicos de construções do passado, ricos em trabalho humano que a sociedade moderna perceberia de maneira cada vez mais nostálgica.

Tudo isso ia contribuindo para estruturar uma linguagem artística relacionada à prática do Grand Tour. Essa linguagem envolvia um temário específico e vocabulário característico, além de um mix de regras de sintaxe visual derivadas de princípios cultivados nas academias de ensino artístico, valores advindos dos hábitos empíricos do registro in loco, modas e afetações da época. É claro que a tradição paisagística da arte européia fornecia uma base sobre a qual as paisagens iam sendo elaboradas durante as viagens, mas, por outro lado, uma arte de paisagem destinada a atender ao gosto dos grand tourists e de seu círculo ia conferindo traços mais específicos à linguagem artística, cheia de particularidades. A arte de veduta, por exemplo, mantém uma relação estreita com viagens, ocupando um lugar importante na produção cultural 
que acompanhou as viagens do século 18 europeu $^{37}$. Dentro da arte de paisagem, a veduta significou um desenvolvimento relacionado a certas necessidades de representação colocadas pelos viajantes europeus à Itália, os quais desde o final do século 17 estavam à procura de uma experiência de representação do país. Os viajantes não desejavam apenas belas imagens, mas também vistas que fossem lembranças visuais de fato do real, isto é, que funcionassem também como registros topográficos. Ainda que a projeção da fantasia pudesse estar presente, turistas queriam levar para casa, ao retornarem, imagens que pudessem documentar, para si mesmos e para seus amigos e parentes, sua estada em um determinado local; que fossem, enfim, registros de memória.

$\mathrm{O}$ vedutismo italiano, que tem em Canaletto seu mais célebre representante, respondeu com muita propriedade ao anseio acima observado. Com suas vistas de Veneza focalizando aspectos característicos da cidade como a Ponte de Rialto, a Praça de San Marco e o Palazzo Ducale, Canaletto encantava de tal modo os aristocratas ingleses que foi levado para a Inglaterra a convite de nobres patronos para produzir vistas também de Londres, tendo por isso exercido uma influência decisiva na arte de paisagem inglesa. Muitos viajantes ingleses que retrataram nossas cidades aqui no Brasil, já no século 19, valeram-se de seus esquemas figurativos e recursos de composição no modo de olhar as cidades, a arquitetura e a animação humana do dia-a-dia dos lugares ${ }^{38}$.

Além de Canaletto, o vedutista e especialista em arquitetura Piranesi, com seus capricci ${ }^{39}$, constituía uma referência obrigatória para o estudo da arquitetura antiga. Suas vistas reunidas e publicadas na Vedute di Roma, coleção de grande sucesso como guia e também para estudiosos e viajantes em geral, eram adquiridas como souvenir e utilizadas na decoração de lares. Sua abordagem imaginativa dos monumentos antigos representou uma atitude inovadora e ousada na especulação da representação do espaço, principalmente de espaços interiores.

Pintores de paisagem na Itália encontravam, assim, um caminho alternativo de sobrevivência. Além da prática dos tradicionais gêneros de retratos, paisagens idealizadas e cenas históricas, e graças à recente figura em cena na arte do século 18 italiano - o turista de gosto, amante da cultura, da arte e da história - muitos artistas vieram a produzir uma arte específica para o viajante, trabalhando para um mercado fundado nesse novo hábito dos ricos - viajar por prazer e para se edificar, tendo o antigo como paradigma.

\section{O CULTO AO SUBLIME}

As viagens européias no século 18 foram também, conforme Monk ${ }^{40}$, responsáveis em grande dose pelo culto ao cenário natural dentro de uma abor- 
dagem estética sublime. Homens de gosto e educados que viajavam para a Itália em busca de arte, história e antigüidades, tinham a oportunidade de, na longa e penosa passagem pelos Alpes, desfrutar do selvagem e do grandioso oferecido pelo cenário da paisagem montanhosa. Os meios de transporte, sempre lentos, a travessia de passes nos Alpes em cadeiras, no lombo de mulas ou mesmo a pé, foram condições técnicas de transporte com irrefutável influência sobre o olhar do viajante, um olhar cuja qualidade era necessariamente outra que a do viajante do século 19 , que já percorria a paisagem dentro do trem a vapor e, depois, pela auto-estrada, em que as coisas vistas se tornavam um "borrão". Na velocidade que a técnica lhe permitia, o grand tourist, ao contrário, dispunha da chance de ver lentamente e admirar-se com alturas nunca antes experimentadas em sua paisagem nativa. Também os sons e o silêncio absoluto eram percebidos em sua forma "limpa", ainda sem a interferência ruidosa da locomotiva e o trabalho incessante da máquina para encurtar as distâncias - exigências da modernidade.

Uma sensibilidade especial acompanhava, pois, o grand tourist, permitindo-lhe viver emoções que seriam transportadas para seus relatos e registros visuais. $\mathrm{O}$ trajeto pelo Monte Cenis, por exemplo, conduzia o viajante ao contato com uma paisagem onde, pela altura das montanhas e precipícios, a visão de uma enorme distância, avalanches, o frio intenso e a neblina espessa, tudo impressionava segundo termos como "infinito", "grandioso", "interminável”, desconhecidos para descrever a paisagem pelos que nunca, até então, haviam deixado sua região de origem, na Inglaterra, França ou Alemanha. Admirar-se com os acidentes e transmitir suas impressões aos que não conheciam os cenários experimentados foi freqüente por muitos viajantes em suas cartas e relatos de viagem como, por exemplo, o novelista inglês Horace Walpole numa carta a um amigo:

(...) [o caminho] enroscava-se em torno de uma montanha imensa, cercada por outras tantas cobertas por uma mata rasteira, obscurecida por pinheiros ou perdida na neblina! Embaixo, a torrente despencava pelos penhascos, descendo por fragmentos de rocha! Cascatas caíam pelos precipícios, correndo para o rio encrespado, lá embaixo! De vez em quando, via-se uma velha pinguela com o corrimão quebrado, um cruzamento inclinado, um casebre ou a ruína de um heremitério! $!^{41}$

Nas artes visuais faziam sucesso os artistas que alcançavam êxito em transmitir a paisagem sublime de montanhas da Itália. O artista Salvator Rosa logo se tornou um dos favoritos do connoisseur inglês, cujas paisagens o viajante facilmente associava à experiência vivida nos Alpes ${ }^{42}$. A estética do sublime, entretanto, passou a ser cultivada sob os mais variados ângulos e com os mais 
diversos temas. Bem ilustrativa dessa diversidade é a obra do pintor inglês Joseph Wright of Derby, que, viajando à Itália entre 1774 e 1775, teve a oportunidade de assistir ao vulcão Vesúvio em atividade eruptiva. Impressionado com o que viu, Wright pintou uma série de cenas noturnas do fenômeno presenciado por ele in situ dentro da mais dramática abordagem sublime, enfatizando efeitos de luz da lava incandescente e do luar pálido, de grande impacto visual.

\section{COMENTÁRIOS FINAIS}

Conforme vimos, fluxos de turismo pela Europa continental no século 18 em direção à península itálica e, mais particularmente, visando à cidade de Roma, se serviram, no início, da rede de comunicações existente para o transporte de correspondência e mercadorias, com o uso de embarcações e carros postais, postos de correios para troca de animais e estradas existentes para esses serviços. Guias turísticos, também, eram ainda informalmente contratados pelo viajante, individualmente em cada lugar, e os guias impressos que surgiam possuíam ainda a forma de relatos de viagem ou de coleções de vistas de lugares, sem o formato dos guias atuais, bastante informativos e sistematizados em seções específicas para facilitar a consulta. Com o passar do tempo, o turismo aristocrático dos Grand Tours foi gradativamente gerando uma infraestrutura turística voltada ao seu público. Pouco a pouco as atividades de transporte, hospedagem e de guia foram se estruturando em serviços especializados, até se tornarem campos de atuação profissional, conduzidos por "especialistas", como ocorre atualmente.

Os diferentes ângulos pelos quais procuramos aqui olhar para os Grand Tours do século 18 representam um esforço para que possamos melhor entender não só essa própria época e seu universo cultural, mas também como muitas das práticas e conhecimentos de que hoje dispomos se originaram e desenvolveram. Modas, preferências de gosto, e muita fantasia, projetadas sobre monumentos, arquitetura e paisagens, indicam também quanto a imaginação humana não tem limites, mesmo quando se trata de descrever locais de fato existentes e narrar experiências, sabendo também quão importante é o papel da tradição no repertório e na linguagem, na descrição da experiência humana do mundo real.

Um aspecto que interessa ainda enfatizar diz respeito justamente às observações que fizemos na introdução deste trabalho sobre a essencial diferença no plano da relação lazer/trabalho entre o Grand Tour e o turismo de lazer dos dias de hoje. Consideramos, no início, que uma característica essencial dos Grand Tours era o fato de que as viagens não se davam em conexão com 
o trabalho. Na verdade, o grand tourist era rico, um privilegiado cujas viagens não eram custeadas pelas economias do seu trabalho. Isso, contudo, é bem diferente do que veio a ocorrer com o turista moderno, aquele do chamado turismo de massa que se expandiu na Europa ao longo do século 19 até os dias de hoje, com muitos "pacotes" para todos os orçamentos, como temos atualmente também no Brasil. A racionalização do tempo na sociedade capitalista moderna criou uma separação entre lazer e trabalho que o grand tourist desconhecia, até porque não trabalhava, mas que o indivíduo moderno vive como um dado quase "natural" do seu mundo. Tornadas acessíveis, em "planos-perfil" bastante variados, as viagens integram hoje quase que obrigatoriamente a pauta do consumo moderno.

Algo parece unir, porém, o antigo grand tourist aos mass tourists contemporâneos, praticantes do turismo em suas variadas versões - turismo cultural, turismo ecológico, turismos praticados por grupos que a própria sociedade capitalista criou, formados por mulheres profissionais independentes que anseiam por lazer, aposentados de uma terceira idade prolongada pelos avanços da medicina, trabalhadores em tempo parcial ou sem horário fixo -, turistas informados, ou assim se representando, e sintonizados com as modas e a consciência ambiental do século 21. Referimo-nos às fantasias de qualquer viagem, igualmente projetadas pelo olhar contemporâneo e que, tal como o olhar do turista "clássico", é um olhar gerador de uma visualidade. Seus contornos, contudo, ainda não permitem ser plenamente percebidos, transcendentes dos registros visuais que fazemos com modernas câmeras fotográficas e filmadoras digitais - apontadas ainda hoje para monumentos, paisagens e cenários -, com o eterno desejo de reter o tempo e uma vez mais estimuladas pela recorrente nostalgia humana do passado, hoje também globalizada.

\section{NOTAS}

${ }^{1}$ SMOLLET, Thobias. Travels through France and Italy. Oxford University Press, 1981.

${ }^{2}$ GOETHE, Johann Wolfgang von. Viagem à Itália 1786-1788. São Paulo: Companhia das Letras, 1999.

${ }^{3}$ KNIGHT, Richard Payne. Expedition into Sicily (ed. Claudia Stumpf). London: British Museum Publications, 1986.

${ }^{4}$ O termo "clássico" foi utilizado por Goethe em seu diário de viagem à Itália, referindo-se a este país de um modo geral. Para Goethe, solo italiano era solo "clássico".

${ }^{5}$ MESSMANN, Frank J., Richard Payne Knight - the Twilight of Virtuosity. The Hague: Mouton and Co. N. V., 1974, p. 23.

${ }^{6}$ BLACK, Jeremy. The British and the Grand Tour. London: Croom Helm, 1985, p.1. 
${ }^{7} \mathrm{SMITH}$, Adam. An Inquiry into the Nature and Causes of the Wealth of Nations (1776), apud MESSMANN. Op. cit., pp. 24-5.

${ }^{8}$ UNY, John. The Tourist Gaze. London: Sage Publications, 1991, p. 4.

${ }^{9}$ BLACK. Op. cit., p. 20.

${ }^{10}$ GOETHE. Op. cit., p. 154.

${ }^{11}$ SMOLLET. Op. cit., p. 304.

${ }^{12}$ Idem, p. 308.

${ }^{13}$ Idem, pp. 64-5.

${ }^{14}$ GOETHE. Op. cit., p. 4.

${ }^{15}$ Idem, p. 268.

${ }^{16}$ HENDERSON, W. O. A Revolução Industrial. São Paulo: Verbo/Edusp, 1979, pp.37-8.

${ }^{17}$ GOETHE. Op. cit., p. 372.

${ }^{18}$ SMOLLET. Op. cit., p. 73.

${ }^{19}$ GOETHE. Op. cit., p. 230.

${ }^{20}$ Idem, p. 170.

${ }^{21} I d e m$, p. 157.

${ }^{22}$ GOETHE. Op. cit., p. 324.

${ }^{23}$ SMOLLET. Op. cit., p. 240.

24"Introdução" da edição de 1981 do diário de viagem de Smollet. Cf. SMOLLET. Op. cit., p. xii.

${ }^{25}$ GOETHE. Op. cit., p. 341.

${ }^{26} \mathrm{Idem}, \mathrm{p} .332$.

${ }^{27}$ Idem, p. 141.

${ }^{28}$ HIBBERT, Christopher, The Grand Tour. London: Methuen, 1987, p. 192.

${ }^{29}$ CLARKE, Michael. The Tempting Prospect. A Social History of English Watercolours. London: British Museum Publications, 1981, p. 60.

${ }^{30}$ Apud MESSMANN. Op. cit., pp. 22-3.

${ }^{31}$ KNIGHT. Op. cit., p. 42.

${ }^{32}$ Claudia Stumpf, editora de Knight. Op. cit., p.18.

${ }^{33}$ Gentleman's Magazine, periódico londrino, edição de setembro de 1823, p. 428.

${ }^{34}$ Idem, edição de agosto de 1824, p. 233.

${ }^{35}$ HYDE, Ralph. Gilded Scenes and Shining Prospects. New Haven: Yale Center for British Art, 1985, p. 19.

${ }^{36}$ MACULAY, Rose. The Pleasure of Ruins. London: Thames and Hudson, 1966. 
${ }^{37}$ Sobre a linguagem da paisagem européia, a arte de veduta, ruínas e a estética do sublime na paisagem ver Salgueiro, Valéria, Gosto, sensibilidade e objetividade na representação da paisagem nos álbuns ilustrados pelos viajantes europeus ao Rio de Janeiro, a Buenos Aires è̀ Cidade do México (1820-1852), 2 vols. Tese de Doutoramento defendida junto à Pós-Graduação em História Social da USP, 1995.

${ }^{38}$ Sobre a linguagem da paisagem de artistas viajantes europeus da primeira metade do século XIX ao Rio de Janeiro, a Buenos Aires e à Cidade do México, ver SALGUEIRO, Valéria. Op. cit., e SALGUEIRO, Valéria. Paisagens de Sonho e Verdade. Rio de Janeiro: Fraiha, 1998.

${ }^{39}$ Capricci (ital.), plural de capriccio: vista resultante de composição fantasiosa, sobretudo da Roma antiga, reunindo numa mesma imagem diversos monumentos, de diferentes locais, com ênfase em seu aspecto em ruína. Cf. Salgueiro, obras citadas.

${ }^{40}$ MONK, Samuel. The Sublime. The University of Michigan Press, 1960.

${ }^{41}$ Trecho de carta de Horace Walpole a seu amigo West, apud HIBBERT. Op. cit., p. 100.

${ }^{42}$ MONK. Op. cit. 